\title{
Electronic Wallet as a Multi Payment Media Solution in the Industrial Revolution Era 4.0: Study on FEBI Students IAIN Sultan Amai Gorontalo, Indonesia
}

\author{
Sofian Sofhian, (i) Mirsa Gulam Da'aliwa ${ }^{2 *}$ \\ ${ }^{122}$ Institut Agama Islam Negeri Sultan Amai Gorontalo, Indonesia \\ *Corresponding Email: irdaaliwa@gmail.com
}

\section{Keywords:}

Electronic Wallet, Multi

Payment, Era of

Industrial Revolution

4.0
ABSTRACT

In line with technological development, all forms of community activity have now shiftedto digitalization, including payment activities. The purpose of this research is to examine and describe whether server-based electronic wallets can be a solution for multi-payment media in the era of the industrial revolution 4.0 for millennial and what electronic wallets better support the needs of multi-payment in the era of industrial revolution 4.0. The method used by the researcher in this research is the descriptive qualitative method. Data collection techniques used are interviews, observation, and documentation. In this study, the data obtained were analyzed using a phenomenological approach which was collected, reduced, presented, and then given a conclusion. The results of this study are that at FEBI IAIN Gorontalo there are 695 students of which 158 students use electronic wallets or about $22.73 \%$. In use, electronic wallets can already be their multi-payment media solution in the era of the industrial revolution 4.0 because of the convenience factor where students can make various payments using smartphones, fast because payments are made only by scanning a QR code, economical because admin fees are cheap and lots of promos. flexible because it can be used anywhere and under any conditions, safe and avoid theft.

Kata Kunci:

Dompet Elektronik, Server, Solusi, Multy Payment, Era Revolusi Industry 4.0

Article Information
Hou To Cite
e-ISSN / p-ISSN

\begin{abstract}
ABSTRAK
Dompet Elektronik Sebagai Solusi Media Multy Payment Di Era Revolusi Industri 4.0 (Studi Pada Mahasiswa Febi lain Sultan Amai Gorontalo). Tujuandilakukannya penelitian ini adalah untuk mengkaji serta mendiskripsikan apakah dompet elektronik berbasis server bisa menjadi solusi media multy payment di era revolusi industry 4.0 bagi kalangan milenial, dan dompet elektronik apa yang lebih menunjang kebutuhan multy payment di era revolusi industry 4.0. Metode yang digunakan peneliti dalam penelitian ini adalah metode kualitatif deskriptif. Teknik pengumpulan data yang digunakan yaitu wawancara, observasi, dan dokumentasi. Dan teknik analisis data dikumpulkan, direduksi, disajikan, lalu diberi kesimpulan. Hasil dari penelitian ini adalah Dompet elektronik berbasis server sudah bisa menjadisolusi media multy payment di era revolusi industry 4.0 karena kemudahan dimana mahasiswa bisa melakukan ragam pembayaran menggunakan smartphone, cepat karena pembayaran dilakukan hanya dengan scan $Q R$ code, ekonomis karena biaya adminnya murah dan banyak promo, fleksibel karena bisa digunakan dimanapun dan dalam kondisi apapun, aman serta terhindar dari pencurian

Received: 21 August 2021; Revised: 10 December 2021; Accepted: 15 December 2021

Volume 1, Number 2, December 2021

Sofhian, S., \&Da'aliwa, M. G. (2021) Electronic Wallet as a Multi Payment Media Solution in the Industrial Revolution Era 4.0: Study on Islamic Economics and Business Faculty Students IAIN Sultan Amai Gorontalo, Indonesia. Talaa - Journal of Islamic Finance, 1 (2), 69-85 https://doi.org/10.54045/talaa.v1i2.267

2807-3002 / 2807-3312
\end{abstract}


Sofhian, S., \&Da’aliwa, M. Q.Electronic Wallet as a Multi Payment_

\section{INTRODUCTION}

In line with the increase of innovationin information and communication technology, the various activities that people do are closely related to the digitalization of technologyeven in economic activities. The increase of innovation is influenced by individual lifestyles in using the internet, for example, searching for data, talking to other people, entertainment, group discussions, and sending files between computers (Latief \& Dirwan, 2020).

A person can get whatever they need through the internet easily, making their life much more practical than before (Intan, Mewengkang, \& Edmon, 2017). In this way, many individuals want to turn to digitization. This transition can be seen when everything conventional has turned into digital, for example regular public transportation and motorcycle taxis into online public transportation and motorcycle taxis, clothing stores into online clothing stores, ordinary food stalls into online food stalls, not least in making payments that initially used cash for making payments, switch to chips/cards (Tazkiyyaturrohmah, 2018).

The existence of a transaction tool in the form of a card aims to the public can minimize the paper money they carry and replace it with only one card (Latief \& Dirwan, 2020) (. But in the current era of the industrial revolution 4.0 where there has been a shift in people's physical activities by combining automation technology with cyber technology (Kagermann \& Wahlster, 2013) which now be done online using a smartphone connected to the internet, making payment methods have experienced upgrade to a server-based electronic wallet (e-wallet). With the presence of electronic wallets in the community, people can carry out various kinds of serverbased financial transactions using smartphones. Considering the community's need for smartphones, which has become a basic need because almost all activities or activities of the community have mostly switched to smartphones, including making various payments.

In Bank Indonesia regulation number 18/40/PBI/2016 Article 1 Paragraph 7 concerning the implementation of payment transaction processing explains that an electronic wallet, referred to as an electronic wallet is an electronic service for storing data on payment instruments including chip-based and chip-based payment instruments. The server uses a mobile application that can be used to accommodate funds, as well as to make various payments. The funds stored in this electronic wallet are called electronic money (Hidayat, 2019).

With the presence of electronic wallets, electronic money in Indonesia is also developing. For this reason, trading via the internet has increased and electronic money has grown so rapidly after the globalization era (Andri, 2016). In Indonesia, Bank Indonesia (BI) has issued regulation Number 20/6/2018 regarding electronic money or e-money.

In simple terms, an electronic wallet is defined as a payment medium in electronic form where the value of electronic money stored in an electronic wallet is the same as the value of rupiah cash in circulation (Rahayu, 2018). The first step in using the electronic wallet is that the user must first deposit the money to the issuer and store it in an electronic wallet before using it for transaction purposes (Bank Indonesia, 2018). The use of this electronic wallet as an innovative and practical payment medium is expected to help smooth payments for mass, fast and microeconomic activities, so that its development can help smooth transactions on toll roads, in the field of transportation such as trains and other public transportation or transactions at minimarkets. ,

The development of a payment instrument known as an e-wallet based server, although it contains slightly different characteristics from other payment instruments such as credit cards and 
Sofhian, S., \&Da'aliwa, M. đ.Electronic Wallet as a Multi Payment_

ATM/Debit cards, the use of this instrument remains the same as credit cards and ATM/Debit cards, which are intended for payments.In this regard, the payment system used by the Indonesian people has also developed (Bank Indonesia, 2020).

In the world of digital payments, server-based e-wallet is developing so fast. In Indonesia, various kinds of server-based electronic wallets are popular, each of which has its mass user base and has been registered with Bank Indonesia, includingthe existence of digital wallets such as OVO, Gopay, Dana, Link Aja makes humans consumptive because of the ease of transaction services through digital (Situmorang, 2021).

This electronic wallet functions as an electronic money storage medium that can be used by the public as a medium of exchange in conducting various transactions. The implementation of electronic money has a positive impact on the activities of electronic money itself in server-based electronic wallets that are aimed at the realization of reduced cash circulation which is often referred to as a less-cash society (Tazkiyyaturrohmah, 2018) and is more effective in its use as a medium for various payments.Server-based or application-based electronic wallets can be used for various non-cash transactions easily, practically and quickly by using a smartphone (Marita, 2012).

The advantages of the e-wallet payment method are that it can be done both remotely or closely, the way to pay for a user's shopping transaction is simply by attaching your cellphone (TAP) or with a QR Code, and you can also transfer balances to each other, payments can be made anywhere, users of E-wallet-based servers usually always get attractive promos from their applications, transactions are guaranteed to be safe because all balance, transaction and personal information are protected by the latest security system, and are licensed and supervised by Bank Indonesia (Berlianingsih, Sulistyo, \& Utami, 2017).

Through the e-wallet service, users can enjoy various types of payment and transaction services, such as conducting long-distance or near-distance transactions at cooperating merchants, paying electricity bills or buying electricity tokens, BPJS (Health Insurance) payments, paying telephone bills and TV subscriptions, purchasing pulses, sharing money with fellow users. By looking at the advantages offered by an e-wallet based server, this shows that electronic wallets allow it to be a solution in making various payments in the current era of the industrial revolution 4.0, where there is an industrial shift by combining automation technology with cyber technology through the internet network (Merkel, 2014).

The development of financial transactions that switch to electronic media is an idea that aims to facilitate the work of the community, especially the millennial generation. The existence of an electronic wallet can also help people make financial transactions at home, considering that the world is currently being hit by the COVID-19 pandemicand Gorontalo is the last area affected by the spread of COVID-19 (Ajuna \& Amri, 2020), of course, the existence of electronic wallets aims to avoid exchanging money in cash in preventing the transmission of COVID-19 through money. At the Faculty of Economics and Islamic Business IAIN Sultan Amai Gorontalo, some of the students have also started to take part in the trend of technological developments in using electronic wallets as a medium for their financial transactions. This phenomenon could happen because apart from being part of the millennial generation, students of the Islamic Economics and Business Faculty of IAIN Sultan Amai Gorontalo should be a pioneer in applying the development of multi-payment media in the world of economy.

From the number of students of Faculty of Islamic Economics and Business in 2017, 2018, and 2019 were 695 students, the number of students using smartphones was 100\%. Meanwhile, 43 people use the Link Aja electronic wallet, 19 people use OVO, 142 people use 
Sofhian, S., \&Da'aliwa, M. đ.Electronic Wallet as a Multi Payment_

DANA, and 9 people use Go-Pay. Of the 695 students at the Faculty of Islamic Economics and Business, the total number of students using electronic wallets at the Faculty of Islamic Economics and Business is 158 or around $22.73 \%$, because some students use more than one electronic wallet application.

The use of electronic wallets among students may increase based on word of mouth information from other students who have used it, even at the Faculty of Economics and Islamic Business, there is one course, namely Non-Bank Financial Institutions which discusses all financial institutions in Indonesia. It includes the Fintech, considering that the electronic wallet company is also one of the Non-Bank Financial Institutions.

Several studies on the use of electronic wallets havebeen done by previous researchers. For example, a study entitled, "The Effect of Electronic Wallet on Indonesian Financial Activities (Comparison of Electronic Wallet Applications owned by Financial Technology Companies to Electronic Wallet Applications owned by SOEs)" (Inggiharti, 2020). This study aims to describe the effect of changing the payment system using electronic wallets on financial activities in Indonesia and to compare the possible losses for the state on transactions using electronic wallets belonging to financial technology companies against electronic wallets owned by SOEs; Then the research entitled, "Interest in Using Cashless Payment System - Digital Wallets for Students at FE UNJ" (Febrilia, Pratiwi, \& Djatikusumo, 2020). Their research aims to examine the effect of: 1) self-efficacy on perceived ease of use, 2) self-efficacy on perceived usefulness, 3) perceived risk to perceived usefulness; 4) perceived risk to intention to use, 5) perceived usefulness to intention to use; 6) perceived ease of use on intention to use, 7) perceived ease of use on perceived usefulness; for digital wallet products for students at FE UNJ; As well as a study entitled, "Is a Sharia-Based E-Wallet Needed?" (Nuha, Qomar, \& Maulana, 2020). Their research aims to describe whether Sharia-based e-wallet is urgent to be presented. "Is a Sharia-Based EWallet necessary?" (Nuha, Qomar, \& Maulana, 2020). Their research aims to describe whether Sharia-based e-wallet is urgent to be presented. "Is a Sharia-Based E-Wallet necessary?" (Nuha, Qomar, \& Maulana, 2020). Their research aims to describe whether Sharia-based e-wallet is urgent to be presented.

The researches above examine electronic wallet from the point of view of its role in state financial activities, measuring how much user interest is, and describing the need for Sharia (syariah) electronic wallets in Indonesia. The difference in this research is that we examine it from a different point of viewnamely from the usefulness of electronic wallets for millennial, so the question arises whether electronic wallets can be a multi-payment media solution in the current era of the industrial revolution 4.0? Thus, this research aims to examine and describe electronic wallets that can be a multi-payment media solution in the era of the industrial revolution 4.0 for millennial.

\section{THEORETICAL BACKGROUND}

\section{Electronic Wallet (E-Wallet)}

\section{The definition Electronic Wallets}

In Bank Indonesia regulation number 18/40/PBI/2016 Article 1 Paragraph 7 concerning the implementation of payment transaction processing explains that an electronic wallet which is then referred to as an electronic wallet is an electronic service intended as a data storage medium 
Sofhian, S., \&Da'aliwa, M. đ.Electronic Wallet as a Multi Payment_

for payment instruments used as a payment medium as a chip and server based applications in the form of applications to accommodate funds, as well as to make payments (Magfirah, 2018).

Purpose and Benefits of Electronic Wallets

The implementation of the electronic wallet service aims to produce innovations that are related to financial technology to meet the needs of the community in carrying out financial activities and are intended as a medium for various payments that are fast, safe, efficient, and reliable.By providing these services, the role of electronic wallets that help facilitate community activities is not only based on the positive law in force in Indonesia, but also based on the Islamic law. As the Word of God in QS Al-Maidah: 2 which is means that: "And help you in (doing) virtue and piety, and do not help in committing sins and enmity" (Ministry of Religion of the Republic of Indonesia: 2010). This verse explains the commandment to help each other in doing good things. This is of course in accordance with the role of electronic wallets that provide convenience to its users. With this convenience, of course, users feel helped,like the command to do mutual help in terms of piety. With Sharia services on the Link Aja server-based electronic wallet, users can easily carry out worship activities ordered by religion such as zakat, alms, waqaf, infaq, hajj, providing qard loans, and buying or giving alms to sacrificial meat.

Meanwhile, according to (Tanayasri, 2017) electronic wallets offer benefits to their users such as:

\section{Convenience}

The ease of transaction is the main advantage of electronic wallets. By using an electronic wallet, users no longer need to carry a thick wallet full of cash, debit/credit cards, or queue up to withdraw cash at an ATM. In addition, electronic wallets are also safer and easier to carry when traveling. In an emergency, using an electronic wallet can make it easier for the public. For example, when they have to pay for online shopping but cannot pay directly because they are unable to do so, users can use electronic wallet services, such as BCA's OneKlik, OVO, LinkAja, and so on.

\section{Discount Promotion}

With the various promotions presented by digital payment services, it will benefit users. Promotions such as cash back or discounts are some of the things that attract users to use these services. Offers on programs such as Pay Day from Go-Pay can be enjoyed by ewallet users. Some also provide reward points and additional free products, such as T-Cash. It can help increase user cash flow marginally.

\section{There is Transaction History}

According to the Economy Times, Outlook Asia Capital CEO Manoj Nangpal said that if all transactions are recorded, users can review expenses regularly, at least once a day. Almost all digital payment services provide transaction history on their applications, like Go-Pay, OVO, T-Cash, and so on. 
Sofhian, S., \&Da'aliwa, M. Q.Electronic Wallet as a Multi Payment_

\section{Budget Discipline}

The transaction history in the digital wallet application makes it easy for users to set a monthly budget for the following month. Users can analyze expenses in a month, and thenapply the results of the analysis to the next month's budget. Budgeting can create discipline in finance because users have set limits on each transaction to be made.

\section{Lower Risk}

If it is stolen, the user can block the e-wallet through the linked account on the mobile device. For this reason, the money in the electronic wallet may no longer be used. Electronic wallet services in Indonesia are also adjusted to the rules of the regulator. In line with BI regulations, the application system for digital payment providers, Dana is integrated with Civil Registry Service data to carry out the KYC process. Through this integrated data, registration of Funds can be done using National Identity Card (KTP) and Family Card $(\mathrm{KK})$.

\section{Implied Advantage}

Indirectly, not having cash allows users to refuse someone who wants to borrow money. Another plus, users can pay the exact amount without worrying about any change from the shop owner.

\section{Definition of Solution}

According to the Great Dictionary of Indonesian Language (KBBI), a solution is a way out or an answer to a problem. A solution is a method or step that is intended to solve or resolve a problem without any pressure. The purpose of the pressure is the objectivity in determining the solution where people who are looking for solutions do not impose their personal opinions and are guided by existing rules or regulations. Otherwise, the solution obtained will be very subjective, so it is feared that it is not the best solution. To get a solution to a problem, several stages that must be passed. First, we need to recognize what exactly the problem is. Then we look for facts or evidence about the problem. After that, we examine what is behind the emergence of these problems.

\section{Industrial Revolution Era 4.0}

\section{The definition of Industrial Revolution 4.0}

The Industrial Revolution 4.0 is the latest trend of automation and data exchange in factory technology including cyber-physical systems, internet for everything, cloud computing and cognitive computing. In short, the notion of the industrial revolution 4.0 is a trend in the industrial world that combines automation technology with cyber technology. (Hermann, Pentek, \& Otto, 2016). 
Sofhian, S., \&Da'aliwa, M. đ.Electronic Wallet as a Multi Payment_

Benefits of the Industrial Revolution 4.0

(VOffice, 2020) Existing smart technologies can help the industry to work more efficiently and effectively without having to spend an excessive budget, different from the previous era which still used conventional labour and technology. Changes, such as the industrial revolution, are made to improve or improve things that already existed before. In industry 4.0 there are three key advantages, namely:

\section{Optimization}

With the industrial revolution 4.0, the most noticeable advantage is production optimization. The development of Artificial intelligence helps the industry to become a Smart Factory, which in the production process uses smart tools. In addition to speeding up the production process, the existence of these tools can minimize expenses.

\section{Customization}

Industry 4.0 encourages customization to create a flexible market, so that it can help meet the needs of the target market quickly and smoothly. This will help close the gap between the company and potential customers, because communication will be easier to do so that it speeds up the sales process and fulfils needs.

\section{Prioritizing Research}

Community demands to be able to keep up with the times will encourage research progress in various fields, one of which is IT or Information Technology. This will encourage education to ensure that the next generation can compete with skills that are appropriate for their time.

\section{The Challenge of the Industrial Revolution 4.0}

According to (Wolter, 2016), to identify the challenges of the industrial revolution 4.0 in the future, namely on issues such as:

a) Information technology security issues.

b) Challenges on reliability and stability of production machines.

c) Challenges in the lack of adequate skill.

d) There is a reluctance to change by stakeholders.

e) The challenge in many jobs is lost because as it changes to automation.

One example of the industrial revolution 4.0 is the battle between conventional taxis and online taxis or basic motorcycle taxis and online motorcycle taxis. Previously, the public did not suspect that ojeks or taxis had successfully increased their benefits with an internet-based application system. The impact of the Industrial Revolution 4.0 with the existence of online motorcycle taxis and taxis is that it is easier for the public to obtain transportation services even at more affordable prices. 
Sofhian, S., \&Da’aliwa, M. Q.Electronic Wallet as a Multi Payment_

\section{Definition of Millennial Generation}

Millenial are those who were born between 1980 until 2000. There are two generations born before the millennial generation, namely the baby boomers and generation $\mathrm{X}$. This millennial generation is full of visionary, innovative ideas, utilizes technology, and emphasizes work performance. The millennial generation has another name, namely Generation $\mathrm{Y}$ or echoes boomers. This generation grew up in the 2000 millennium century, along with the development of information technology and the internet which as fast as Flash changed the face of the world (Marcomm, 2008).

The millennial generation was born in the era oftechnological advances, Gen Y's behavior is very dependent on internet technologyto findvarious information beforedeciding to purchase aproduct or use a service. Theyhave a positive view of howtechnology and information affecttheir lives than generationsbefore, they could do anythingactivities very easily thanks to the helpof technology (Hidayatullah, Warris, Devianti, Sari, Wibowo, \& Made, 2018).

\section{METHODOLOGY}

The research method used is qualitative research. The research approach used by the researcher in this study is a descriptive analysis research method, namely a research mechanism that produces descriptive data in the form of written or spoken words from people and observable behavior (Sugiyono, 2017). The type of research that the researcher uses is field research which aims to find out whether server-based electronic wallets can be a multi-payment media solution in the industrial revolution 4.0 era among millenial. The data source used is primary data obtained directly from the research subject by using a measuring device or data collection tool directly from the subject (Chalid \& Abu, 1997), which is sourced from in-depth interviews conducted by researchers with students who use electronic wallets at the Faculty of Islamic Economics and Business IAIN Sultan Amai Gorontalo. However, due to the ongoing COVID-19 pandemic, the researchers conducted online interviews via Whatsapp by video call.

Interviews were conducted with students who are active in using the electronic wallet. This is because, from the initial observations made by researchers, most students use electronic wallets that are passive and even operate only once to fulfill their coursework needs.

In addition, research also useda phenomenological approach in understanding and interpretingthe experience of informants related to research phenomena (Ghony \& Almanshur, 2012).The concept in phenomenology is that every symptom that appears consists of a series of participants who surround it, it is the root of qualitative research, and the problem in question is caused by the subject's view (Sujarweni, 2015). Researchers in analyzing the data start by examining all the data that has been collected, then read and studied, and the next step involves three components of data analysis, namely: data reduction, data presentation, and concluding (Arikunto, 2010). 
Sofhian, S., \&Da'aliwa, M. Q.Electronic Wallet as a Multi Payment_

\section{RESULTS AND DISCUSSION}

\section{Research Findings}

To find out students' views about whether or not server-based electronic wallets can be a payment media solution in the current era of the industrial revolution 4.0, the researchers conducted interviews with 15 students, 3 students as LinkAja users, 3 students as OVO users, 3 students as DANA users, 3 students as Go-Pay users, 1 LinkAja, DANA, and OVO users, and 2 as LinkAja, OVO, DANA, and Go-Pay users. The results of interviews that researchers obtained are as follows:

\section{Student Views as LinkAja Electronic Wallet Users}

The researcher interviewed Sardi Djulia who is an active student in the Islamic Banking Department in semester 8. He stated that:

"Financial activities that are often carried out are money transfers, online shopping, top up credit, and others. The reason for making transactions on LinkAja is because it's easy, you pay for nothing, so you don't use a cellphone, you only get it when you pay because you don't have to scan the barcode, so there's no need to wait for change, after that it's safe to save money on LinkAja because there is no such thing as a moot of money or new people stealing your money because they are monitored by Bank Indonesia, then another reason is because it is halal.Link Aja has a sharia service department. The advantages of transacting on Link Aja that I feel are many, one of which is that you don't have to carry a lot of money in your wallet. The risk that you can feel is that when you do top-up sometimes you can't because of the network. Yes, electronic wallets can be a payment media solution in the current era

Based on the results of the interview above, the reason Sardi chose to use Link Ajawas because according to him, using LinkAja, financial transactions that he usually did become easier because they can be done anywhere, fast because there was no need to wait for change and only need to scan a QR code, it was safe because it was supervised by Bank Indonesia, made payments, and was halal because Link Aja has sharia services. The risk that Sardi has experienced while using Link Aja is that he cannot top-up his balance when the internet network is less stable. Sardi said that the factors that influence the millennial generation using electronic wallets are convenience and electronic wallets have followed the times. According to him, the Link Aja electronic wallet can already be a multi-payment media solution for the needs of financial transactions.

Apart from Sardi Djulia, the researcher also interviewed two other students using Link Aja, namely, Andri Taher, who was a 4th semester student of the Sharia Banking Department and Melani Ibrahim, who was a 8th semester student of the Sharia Banking Department. Both students confirmed that electronic wallet is a solution for their multi-payment in the current era of the industrial revolution 4.0. 
Sofhian, S., \&Da'aliwa, M. Q.Electronic Wallet as a Multi Payment_

\section{Student Views as OVO Electronic Wallet Users}

The researcherinterviewed Hamsil Hamdi who was an active student in the 6th semester of the Islamic Accounting Department. He stated that:

"For the transactions themselves, there are many, for example, top-up credit, top-up diamond games, and being able to transfer money to my mobile banking, then pay for clothes on online orders. I use an electronic wallet because it provides very easy facilities, of course, making it easier for me when I want to make financial transactions that I often do. The advantage is that it makes it easy for me to make transactions from anywhere. Then the products offered are very affordable, for example, if we want to top up credit, it is only based on the price, for example, if we want to buy 100,000 credits, the price is also Rp. 100,000. It's different with me buying at other counters, for example, I want to buy 100,000 credits, the price is Rp. 105,000, and some even Rp. 110,000. So that's the advantage of using an e-wallet, no need to depend on others anymore. If there is a risk, when you want to make a transaction in a tight situation but your internet connection is not good, you can't make a transaction. The influencing factor is that, convenience, lots of variations offered with various uses, especially if we make purchases nowadays many use QR Codes, so if we want to pay for something without having to bother spending a dime to pay something we buy, because we just need to scan and find out how much it costs, even if the denominations reach hundreds of rupiah, using this electronic wallet there is no need for change, it is safe and secure. Electronic wallets can really be a financial solution in today's era."

Based on the interview results above, the reason Hamsil chose to use OVO was that according to him using OVO, the financial transactions he usually did became easier because they could be done anywhere and anytime, fast because the payment method could only be scanned a QR code, the price of pulses that cheap, cheap admin fees to top-up, and safe transactions because they are supervised by Bank Indonesia. The risk that Hamsil experienced when making transactions was not being able to make transactions when the internet network was less stable. According to him, the OVO electronic wallet can already be a multi-payment media solution for the needs of financial transactions.

Apart from Hamsil, the researcher also interviewed two other OVO user students, namely, Safitri Mohi who is a student majoring in Islamic Accounting in semester 8 and Hijrahwati Tahir who is a student of the Department of Islamic Economics in semester 2. Both said that the OVO electronic wallet could be a solution for multi-payment media for the needs of their financial transactions.

\section{Student Views as DANA Electronic Wallet Users}

The intervieweeis Sri Yolanda Hasbih who was an active student in Islamic Economics semester 8 . She stated that, 
Sofhian, S., \&Da'aliwa, M. Q.Electronic Wallet as a Multi Payment_

"Financial activities that I often do in electronic wallets are payment of light pulses, payment of cellphone credits, and transfers to Bank BRI. Using an electronic wallet makes every transaction easier, you don't need to leave the house if you want to buy cellphone credit, light pulses, and transfers to banks can be through cellphones without leaving the house. The advantage is that it makes it easier without having to leave the house; it is more efficient and practical for a boarding student like me. Until now there is no risk after using an electronic wallet, because it is more practical and safe, and also the most sought after millennial generation like me who is easy and can be accessed at any time. And I think it's okay."

Based on the interview above, the financial transactions that Yolan often did payments for credit, electricity credit, and making transfers to BRI bank accounts. The reason Yolanmade transactions using DANA was that it makes easier for every transaction that can be done without leaving the house and is practical to use. So far, Yolan had not encountered any risks while using the DANA electronic wallet. And according to him, electronic wallets can already be a solution for payment media in the current era.

Apart from Yolan, the researcher also interviewed two other DANA user students, namely, Pratiwi Badu who is an active student in the Sharia Financial Management Department in semester 6 and Mutia Safira Data, a student in the Department of Sharia Banking in semester 8. Both of them said that DANA's electronic wallet could be a media solution. Multi payment for their financial transaction needs in the current era.

\section{Student Views as Go-Pay Electronic Wallet Users}

The interviewee is Yulan G. Bula who was an active student in the 4th semester of the Islamic Accounting Department. He stated that:

"Financial transactions that I often do with electronic wallets are in the form of giving zakat to mosques, buying credit and electricity tokens, shopping at Alfamart and Indomaret, and making cash withdrawals. The reason I make transactions using an electronic wallet is to make it easier for us so we don't go anywhere else, considering that we are currently in a pandemic. The advantage of transacting using an electronic wallet that I have felt is that it is very easy and affordable. The risks that I feel while making transactions using Go-Pay are internet network disturbances and data disturbances. Electronic wallets can certainly be a solution for my financial transactions in the current era because we can see together that this electronic wallet is very safe for us."

Based on the interview above, the financial transactions she often does are donating to mosques, buying credit and electricity tokens, shopping at Alfamart and Indomaret, and making money withdrawals. The reason Yulan chose to use Go-Pay is because it is easy to make transactions and can be done anywhere and it's safe to use. The risk that Yulan experienced when making transactions using the Go-Pay electronic wallet was that she couldn't make transactions when the internet network was unstable and when she didn't have an internet quota. In her opinion, the Go-Pay electronic wallet can already be a multi-payment media solution for the needs of financial transactions in the current era. 
Sofhian, S., \&Da'aliwa, M. đ.Electronic Wallet as a Multi Payment_

In addition to Yulan, the researcher also interviewed two other Go-Pay students, namely, Ulfa Aulia Mahmud who was a student of the Islamic Banking Department in the 8th semester and Susianti Kaoming who is a student of the Islamic Economics Department in the 8th semester. Both said that the Go-Pay electronic wallet could be a solution. Multi-payment media for their financial transaction needs in the current era.

\section{Discussion of Research Results}

The presence of this server-based electronic wallet certainly aims to keep up with technological developments in this era of the industrial revolution 4.0. Community life, including students themselves, cannot be separated from the influence of smartphones because almost all student activities are very dependent on smartphones. Starting from learning activities, socializing, obtaining information or news, and so on, students do using smartphones (Intan, et al: 2017) which previously had to be done more physically. Because of this, new innovations were born regarding the ease of financial activities ranging from buying to paying for something that must be done in a certain place or situation and it can be done using a smartphone in various places and under any circumstances.

Electronic wallets have many benefits to offer their users. From the results of the research that the authors obtained from students who have used electronic wallets, they conveyed various variants regarding the benefits of using these electronic wallets, including:

Easy

Electronic wallets provide convenience to their users. (Davis, 1989) defines Perceived Ease of Useas a belief in ease of use, namelythe degree to which the userbelieves that the technology or system can be used easily and problem-free. Meanwhile, the ease of use according to (Jogiyanto, 2007) defined as the extent to which a person believes that using a technology system will be effortless. By using an electronic wallet, users can make various payments ranging from paying bills, paying credit, transferring money to bank accounts or to fellow electronic wallet users, sharing, paying for the purchase of goods or food and drinks, paying for transportation, and other payments can be made by using only an application that can be downloaded on a smartphone. Financial transactions using electronic wallets can be done by users anywhere and anytime. Users also don't need to carry a lot of money to carry out financial activities if they already use an electronic wallet. Thus, using an electronic wallet makes financial activities easier.

The ease will appear when someone uses a method or tool in carrying out an activity compared to using the usual ways, because basically, a system or tool was created to make it easier for humans to do their activities. For example, someone will find it easier to lift a large rock with heavy equipment than with human power manually. Indicators of ease of use according to (Jogiyanto, 2007) who modified the instrument from (Davis, 1989) include: 1) Easy to learn, 2) Easy to understand, 3) Simple, 4) Easy to operate. For this reason, the use of electronic wallets among students of the Faculty of Economics and Islamic Business gains convenience in conducting financial transactions. 
Sofhian, S., \&Da'aliwa, M. đ.Electronic Wallet as a Multi Payment_

Fast

In an advanced era like today, people no longer need to find it difficult to leave the house to shop because there are already many applications that provide online buying and selling services (Sisca, 2020). In general, if someone wants to carry out financial activities, whether it's payments or purchases, they must be done by moving from their residence. Several times, phenomena often occur when making financial transactions; someone usually has to wait for change. By using an electronic wallet, users can make financial transactions quickly without even leaving their homes. Especially during the COVID-19 pandemic, digital wallets are increasingly being used as a means of payment because they do not need to be in contact with money (cashless).

The nature of digital wallets is indeed to replace the existence of physical wallets with paper money, coins, cards, and so on (Olsen \& Vatrapu, 2011). Payment methods can be made online and can also be done simply by scanning a QR code, so users can make payments with the right amount, quickly without waiting for change.

\section{Economical}

Electronic wallet users also usually get discount promos in the form of discounts from electronic wallet providers when making transactions. (Kotler \& Keller, 2009) states that discounts are basic price adjustments to reward customers for certain reactions, such as early bill payments, volume purchases and off-season purchases. The prices offered are in the form of various pulses, game diamonds, and very cheap top-up fees. Even for topping up their own balances, there are several electronic wallets with their cooperating merchants, no admin fees are charged, as well as by transferring money to a bank account; the admin fees are very cheap and even free. For this reason, deciding to carry out financial activities using an electronic wallet can also make users live more economically.

\section{Flexible}

Usually, when someone wants to make a financial transaction right away but he forgets to put his smartphone, he can still make the transaction using the smartphone of a relative, friend, or relative who is around him to transact. Even when someone leaves his house and forgets to bring his wallet or smartphone, so that at a certain time he wants to do financial activities but he misses his wallet or smartphone, he doesn't make transactions. However, if he uses an electronic wallet, he no longer needs to worry when he wants to make financial transactions when his wallet or smartphone is left behind, because if he has an e-wallet account, he can open his account on someone else's smartphone.

\section{Safe}

With the transition of the industry to 4.0 , the public, especially students, is starting to realize that personal data is very vulnerable to being misused by platform owners. Therefore, the wider and deeper digital adoption due to the pandemic will encourage consumers to be more concerned about the privacy and security of personal data (Yushowandy, 2021). By using an electronic wallet, users do not have to worry about the balance in the electronic wallet will be 
Sofhian, S., \&Da'aliwa, M. đ.Electronic Wallet as a Multi Payment_

lost, because this electronic wallet is monitored by Bank Indonesia. In addition, users also no longer need to carry a lot of money and worry about theft because the user's money is stored in a very secret media and is not easily taken by others. This is because the electronic wallet is facilitated by a PIN (Personal Identification Number) which is only known by the user himself. Even when making transactions, electronic wallets also provide a transaction history feature. Thus, all users' financial transaction activities can be monitored and as evidence of the user himself. So that transacting using an electronic wallet is certainly more secure.

All of the reasons for the advantages of electronic wallets above have met the criteria of the industrial revolution era 4.0. This is because in the industrial revolution 4.0 era, almost all human activities, including multi-payment activities, can now be transferred to online media by relying on smartphones. The presence of electronic wallets in the era of the industrial revolution 4.0 will certainly provide benefits to the community, especially the students themselves in carrying out their financial activities. Especially during the current COVID-19 pandemic where the government recommends that financial transactions be carried out non-cash, the presence of electronic wallets is also very helpful for the community, especially students, in conducting noncash financial transactions to avoid transmission of the virus through cash.

Electronic wallets can already meet the criteria of the current 4.0 industrial revolution. The presence of industrial revolution 4.0 aims to make human activities more optimal by using media connected to an internet connection. The emergence of this electronic wallet has answered the challenges of the industrial revolution 4.0 era, which initially financial activities such as payments and purchases of goods had to be done at a certain place and time, now with the presence of an electronic wallet, users can make these transactions anywhere and anytime as long as they are connected to the internet network.

From the findings that researchers have discussed about whether or not electronic wallets can become a multi-payment media solution in the era of the industrial revolution 4.0, all students who use electronic wallets who are used as informants by researchers say that serverbased electronic wallets are very helpful for their financial activities in the current era, so the author concluded that server-based electronic wallets can already be a multi-payment media solution in the current era of the industrial revolution 4.0.

\section{CONCLUSION}

From the findings that the researcher has discussed above, the researchers conclude that the results of interviews that researchers conducted with students at the Faculty of Islamic Economics and Business IAIN Sultan Amai Gorontalo, where researchers divided them into 4 electronic wallet providers, namely Link Aja, OVO, DANA, and Go-Pay. They said that server-based electronic wallets have become a multi-payment media solution in the era of the industrial revolution 4.0, where human activities that were originally done conventionally are now turning to online media which aims to facilitate human activities themselves. This is because by using an electronic wallet, financial transactions become easier, faster, economical, flexible, and of course safe, especially with the current state of the world like today's pandemic. 
Sofhian, S., \&Da'aliwa, M. Q.Electronic Wallet as a Multi Payment_

\section{REFERENCES}

Aji, H., \& Husin, M. (2020). COVID-19 and e-wallet usage intention : A multigroup analysis between Indonesia and Malaysia. Cogent Business \& Management Vol.7 (1).

Ajuna, L., \& Amri, M. (2020). Woman Workers And Their Economic Roles During COVID-19 Outbreak From An Islamic Perspective: A Case Of Bentor Drivers in Gorontalo, Indonesia. Tala'a Journal Of Islamic Finance .

Andri, S. (2016). Bank dan Lembaga Keuangan Syariah. Jakarta: Kencana.

Arikunto, S. (2010). Metode Penelitian. Jakarta: PT Dunia Pustaka.

Bank Indonesia. (2018). Peraturan Bank Indonesia Tentang Uang Elektronik.

Berlianingsih, Sulistyo, K., \& Utami, S. (2017). Faktor-Faktor yang Mempengaruhi Minat Penggunaan E-Money Studi Pada Mahasiswa STIE Ahmad Dahlan Jakarta.

Bhattacherjee, A. (2001). Understanding Information Sistems Continuance: An ExpectationConfirmation Model. 25(3), 351-370.

Buttle, F. (2007). Customer Relationship Managemen. Malang: Bayumedia Publishing.

Chalid, N., \& Abu, A. (1997). Metodologi Penelitian. Jakarta: Bumi Aksara.

Davis, F. (1989). erceived Usefulness, Perceived Ease of Use, and User Acceptance of Information Technology. 13/3, 319-339.

Depdiknas, P. B. (2005). Kamus Besar Bahasa Indonesia. Jakarta: Balai Pustaka.

Echols, J. M., \& Shadily, H. (2000). Kamus Inggris-Indonesia. Jakarta: Gramedia.

Febrilia, I., Pratiwi, S., \& Djatikusumo, I. (2020). Minat Penggunaan Cashless Payment SystemDompet Digital Pada Mahasiswa Di FE UNJ. JRMSI, 11 No.1, 1-19.

Ghony, M. D., \& Almanshur, F. (2012). Metodologi Penelitian Kualitatif. Jakarta: Ar-Ruzz Media.

Hermann, Pentek, \& Otto. (2016). Design Principles for Industrie 4.0 Scenarios.

Hidayat, M. T. (2019). Pengukuran Penerimaan Pengguna Dompet Elektronik Berbasis Server Di Tanggerang Selatan Menggunakan UTAUT 2. 
Sofhian, S., \&Da’aliwa, M. Q.Electronic Wallet as a Multi Payment_

Hidayatullah, S., Warris, A., Devianti, C., Sari, R., Wibowo, A., \& Made, P. (2018). Perilaku Generasi Milenial Dalam Menggunakan Aplikasi Go-Food. Jurnal Manajemen \& Kewirausahaan , 6(2), 240-249.

Inggiharti, N. (2020). Pengaruh Electronic Wallet terhadap Kegiatan Keuangan Indonesia (Perbandingan Aplikasi Electronic Wallet Milik Perusahaan Financial Technology terhadap Aplikasi Electronic Wallet milik BUMN). Law Jurnal. 5(1).

Intan, D. T., Mewengkang, N., \& Edmon, K. R. (2017). Penggunaan Smartphone Dalam Menunjang Aktivitas Perkuliahan Oleh Mahasiswa Fispol Unsrat Manado.

Jogiyanto. (2007). Sistem Informasi Keprilakuan. Yogyakarta: Penerbit Andi.

Kagermann, L. H., \& Wahlster, W. (2013). Final report: Recommendations for implementing the strategic initiative INDUSTRIE 4.0. Industrie 4.0 Working Group.

Kotler, P., \& Keller, K. L. (2009). Marketing Management 13e. Jakarta: Erlangga.

Latief, F., \& Dirwan. (2020). Pengaruh Kemudahan, Promosi, Dan Kemanfaatan Terhadap Keputusan Penggunaan Uang Digital.

Magfirah. (2018). Faktor-Faktor Yang Mempengaruhi Sistem Pembayaran Go-Pay.

Marita, L. S. (2012). Metode Pembayaran Belanja Dengan E-Commerce. Cakrawala . 12(2), 105113.

Merkel, A. (2014). Speech by Federal Chancellor Angela Merkel to the OECD Conference. Retrieved August 18, 2021, from ://www.bundesregierung.de/Content/EN/Reden/2014/2014-02-19-oecd-merkelparis_en.html

Nuha, U., Qomar, M. N., \& Maulana, R. A. (2020). Perlukah E-Wallet Berbasis Syariah?. Journal of Islamic Banking and Finance . 4 (1).

Olsen, M. H., \& Vatrapu, R. (2011). E-wallet Prototypes. International Conference on Design Science Research in Information Systems (pp. 223-236). Berlin, Heidelberg: Springer.

Rahayu, R. W. (2018). Pengaruh Persepsi Manfaat, Persepsi Kemudahan, Persepsi Risiko dan Inovasi Teknologi Terhadap Aplikasi Go Pay dari Gojek Indonesia Studi Pada Masyarakat di Kabupaten Sleman dan Kota Yokyakarta.

Sisca, A. (2020). Pola Perilaku Konsumen Digital Dalam Memanfaatkan Aplikasi Dompet Digital. 
Sofhian, S., \&Da'aliwa, M. C..Electronic Wallet as a Multi Payment_

Situmorang, M. K. (2021). Pengaruh Perilaku Konsumen Terhadap Penggunaan Uang Elektronik (Dompet Elektronik) Sebagai Alat Pembayaran Pada Masa Pandemi COID-19 di Kota Medan.

Sugiyono. (2017). Metode Penelitian Kuantitatif, Kualitatif, Dan R\&D. Bandung: Alfabeta.

Sujarweni, V. W. (2015). Metodologi Penelitian Ekonomi dan Bisnis. Yogyakarta: Pustaka Baru Press.

Tazkiyaturrohmah, R. (2016). Transaksi Uang Elektronik di Tinjau dari Hukum Syariah. . (2018). Eksistensi Uang Elektronik Sebagai Alat Transaksi Keuangan Modern. Muslim Heritage. 3(1).

Yushowandy. (2021).

Retrieved

August

19 , 2021,

from https://www.yuswohady.com/2020/08/26/5-digital-consumer-megashifts-2

Copyright Holder:

(C) Sofhian, S. \&Da'aliwa, M. G. (2021)

Publication Right:

Talaa : Journal of Islamic Finance

Department of Sharia Financial Management IAIN Sultan Amai Gorontalo, Indonesia

(cc) BY-SA 